\title{
Physical properties of waterlogged vertisols under subsurface drainage system with different drain spacings and depths
}

\author{
SHRIMANT D. RATHOD, SUDHIR D. DAHIWALKAR, SUNIL D. GORANTIWAR, BHIMRAO M. \\ KAMBLE AND MUKUND G. SHINDE
}

Received : 12.01.2017; Revised : 07.02.2017; Accepted : 21.02.2017

See end of the Paper for authors' affiliation

Correspondence to :

SHRIMANT D. RATHOD

NARP, Agricultural Research

Station, Kasbe Digraj, Tal.

Miraj, SANGLI (M.S.) INDIA

Email : sdrathod2004@

gmail.com
- ABSTRACT : The field investigation entitled "Physical properties of waterlogged Vertisols under subsurface drainage system with different drain spacings and depths" was conducted on farmer's field at village Mouje Digraj which was located $3 \mathrm{~km}$ away from Agricultural Research Station, Kasbe Digraj, district Sangli (Maharashtra), India during Adsali sugarcane season (16-18 months crop duration) of 2012-13 to 2013-14. In order to fulfill the objective of the study, the bulk density, particle density, total porosity and basic infiltration rate of soil were determined at initial and 18 months after drainage with respect to twelve treatment combinations consisting of four drain spacings of $(10,20,30$ and $40 \mathrm{~m})$ and three drain depths $(0.75,1.0$ and $1.25 \mathrm{~m})$. It was found that the subsurface drainage system with drain spacing of $10 \mathrm{~m}$ and drain depth of $1.25 \mathrm{~m}$ recorded highest per cent improvements in bulk density (20.99\%), particle density (6.10\%), total porosity $(13.74 \%)$ and basic infiltration rate of soil $(13.75 \%)$ following 18 months of drainage. However, these per cent improvements in physical properties of soil under different treatment combinations of drain spacings and drain depths were followed decreasing trends from the closer to wider spaced drains under fixed drain depth i.e. $10 \mathrm{~m}>20 \mathrm{~m}>30 \mathrm{~m}>40 \mathrm{~m}$ and from deeper to shallower drain depth under fixed drain spacing i.e., $1.25 \mathrm{~m}>1.0 \mathrm{~m}>0.75 \mathrm{~m}$. Further, the difference between maximum and minimum values of per cent improvement of these physical properties of soil among 12 different treatments combinations were not too large (3.05 to 8.41\%) which was within the 10 per cent variation. Considering the economics of twelve different combinations of drain spacings and drain depths, the drain spacing of $40 \mathrm{~m}$ and drain depth of $1.25 \mathrm{~m}$ were found optimal for economically feasible production of sugarcane and optimum physical properties of waterlogged Vertisols of Maharashtra.

- KEY WORDS : Drain spacings, Depths, Physical properties, Subsurface drainage system, Sugarcane, Waterlogged vertisols

- HOW TO CITE THIS PAPER : Rathod, Shrimant D., Dahiwalkar, Sudhir D., Gorantiwar, Sunil D., Kamble, Bhimrao M. and Shinde, Mukund G. (2017). Physical properties of waterlogged vertisols under subsurface drainage system with different drain spacings and depths. Internat. J. Agric. Engg., 10(1) : 22-30, DOI: $10.15740 / H A S / I J A E / 10.1 / 22-30$. 